\title{
Dengue virus infection: A review of advances in the emerging rapid detection methods
}

\author{
Mubashir HUSSAIN ${ }^{1}$; Zeeshan ALI ${ }^{1}$; Bin LIU ${ }^{2}$; Jianguo DAI ${ }^{1}$; Xiaolong LIU ${ }^{1}$; Junchen ZHU ${ }^{1, *}$; YongJun TANG ${ }^{1, *}$ \\ ${ }^{1}$ Postdoctoral Innovation Practice, Shenzhen Polytechnic, Shenzhen, 518055, China \\ ${ }^{2}$ Key Laboratory of Clinical and Medical Engineering, Department of Biomedical Engineering, School of Biomedical Engineering and Informatics, Nanjing \\ Medical University, Nanjing, 211166, China
}

Key words: Dengue virus, Rapid detection methods, Electrochemical methods

\begin{abstract}
Dengue virus infections are increasing worldwide generally and in Asia, Central and South America and Africa, particularly. It poses a serious threat to the children population. The rapid and accurate diagnostic systems are essentially required due to lack of effective vaccine against dengue virus and the progressive spread of the dengue virus infection. The recent progress in developing micro- and nano-fabrication techniques has led to low cost and scale down the biomedical point-of-care devices. Starting from the conventional and modern available methods for the diagnosis of dengue infection, this review examines several emerging rapid and point-of-care diagnostic devices that hold significant potential for the progress in smart diagnosis tools. The given review revealed that an effective vaccine is required urgently against all the dengue virus serotypes. However, the rapid detection methods of dengue virus help in early treatment and significantly reduce the dengue virus outbreak.
\end{abstract}

\section{Introduction}

The dengue virus (DENV) belongs to the Flavivirus genus to the Flaviviridae family and is transmitted from Aedes spp. mosquitoes to humans. The spread of virus is by a human to mosquito to human cycle transmission (Simo et al., 2019). Global climate change has influenced the interactions of mosquito species with their hosts (Tabachnick, 2016). There are various environmental and social changes are involved that have affected the epidemics of DENV. Several factors including climate change, poverty, public sanitation policy, and improper rural-urban gradient (Ali et al., 2017). Dengue virus has infected more than 100 countries all over the world. Every year, around 400 million people get infected with dengue virus, and 96 million people show severe symptoms with 20,000 deaths, approximately (Durbin, 2019; Kumar et al., 2020). The World Health Organization (WHO) distributes the Dengue Haemorrhagic Fever (DHF) in four different categories (I-IV). DHF categories I and II signify comparatively mild cases without shock, whereas cases with categories III and IV are more severe and accompanied by shock (Martina et al., 2009).

*Address correspondence to: Junchen Zhu, zjc@szpt.edu.cn; Yongjun Tang, tangyongjun@szpt.edu.cn

Received: 02 March 2021; Accepted: 10 May 2021
Till 2013, dengue fever was believed to be caused by four serotypes of DENV (DENV-1, DENV-2, DENV-3, and DENV-4) that can spread the DENV infection, ranging from asymptomatic infection to dengue fever (DF) (Whitehead et al., 2007). The four serotypes are antigenically distinct and are genetically similar, with approximately sharing $65 \%$ of their genome sequence (Darwish et al., 2018). DENV-5 is the newest serotype reported by Dennis Normile in October 2013 (Normile, 2013). The symptoms of the patient infected by DENV-5 were attributed to sylvatic DENV-4 strains (Mustafa et al., 2015). Some of the serotypes can cause severe diseases than others. Early serotyping can give early warning of dengue epidemics for providing better management of patients and public health surveillance (Tsai et al., 2019).

The dengue was conventionally divided into four main categories: non-classical DF, classical DF, dengue hemorrhagic fever (DHF), and dengue shock syndrome (DSS) (Ajlan et al., 2019). The new classification of dengue by World Health Organization (WHO) classifies the dengue into two main categories: severe and non-severe dengue. The severe dengue includes DHF and dengue shock syndrome (DSS) and are the most severe form of DENV infections (Pang et al., 2017). The non-severe dengue is further divided into dengue with warning signs and dengue without warning signs (Kuo et al., 2018). Any of the DENV 
serotypes can cause different infections that may be asymptomatic in many of the cases. The most symptomatic infections are known as classic DF with an incubation period of 3-14 days but is generally 4-7 days (Chumpu et al., 2019; Hsieh, 2017). DF causes a high fever with general symptoms of headache, nausea, vomiting, muscle pain, generalized myalgias and arthralgias, and anorexia (Azeredo et al., 2018; Lee and Rose, 2018). Approximately 50-100 million DENV infections are causing more human diseases than any other arbovirus (Darcy et al., 2020; Meyding-Lamadé and Craemer, 2018). The numbers of DENV infected cases are continuously growing in endemic areas of Africa, Southeast Asia, Central, and South America, the Caribbean, and the Pacific (Halstead, 2006; Jelinek, 2009; Linn et al., 2020). Recent studies have shown that children with 5-15 years of age are more susceptible to DSS due to weak immune system (Rahmasari et al., 2020). It remains a leading cause of hospitalization in at least eight Southeast Asian countries (van Panhuis et al., 2015).

No approved dengue vaccine is currently available because it is complicated to develop a DENV vaccine causing Antibody-Dependent Enhancement (ADE) (Shukla et al., 2020). The cross-reactive sub-neutralizing antibodies in $\mathrm{ADE}$ increase the viremia levels. In $\mathrm{ADE}$, nonneutralizing antiviral protein facilitates receptor-mediated enhanced entry into host cells to replicate the infected cells (Billings et al., 2007; Chen et al., 2016). The higher number of infected cells in the human body can trigger lifethreatening infections (Cabezas et al., 2018). A chimeric dengue virus vaccine based on yellow fever has been employed and has shown some effective results against all four dengue serotypes. The vaccine has been evaluated in Phase III efficacy trials (Coudeville et al., 2016). Several other candidate vaccines are under clinical trials of phase I-III that have been assessed for different serotype immunity (Liu et al., 2016; Schwartz et al., 2015). Therefore, it is necessary that a successful DENV vaccine should produce a protective immune response against all serotypes.

Before the approval of clinical vaccine and its production, the development of an early diagnostic system plays a vital role in reducing the DENV infection fatality rate. Dengue is a pyretic disease that causes fever in human body. Therefore, it is essential to provide a differential diagnostic system between dengue infection and other pyretic diseases (Beltrán-Silva et al., 2018). The wrong diagnosis is also risky for patient health and further treatment (Tchuandom et al., 2019). The incorrect diagnosis of the fever could lead to misleading results as malaria or pneumonia, which can cause ineffective and expensive overtreatment (Chong et al., 2017). Recently the increase in dengue virus infection among various countries has led to developing a rapid and miniaturized point-of-care (POC) test for dengue diagnosis (Jain et al., 2021). The POC tests are essential, especially in remote areas with limited resource settings, where the highly cost diagnostic tests are not possible to perform (Hussain et al., 2020a; Hussain et al., 2020b; Hussain et al., 2020c) (Eivazzadeh-Keihan et al., 2020). The development of dengue diagnostic tools is improving with the advancement in micro- and nanofabrication bioelectronic devices. Many studies are being performed, and some are under the clinical trial phases for the development of diagnostic prototypes (Nazemi et al., 2019).

The antigen-based assays have been proven to be useful for the detection of the dengue NS1 protein. The diagnosis of the dengue virus is dependent on the phase of infection. In recent years, lateral flow or immunochromatographic strip tests have been successfully developed in developing countries because its sample preparation is not complicated. These devices can be manufactured at low costs and reliable diagnosis without any use of electronic devices. However, there are some disadvantages associated with LFAs including complicated steps, time consuming, and requires skilled operator. Although LFAs are known as POCT methods but various existing LFAs lack sensitivity (Chen et al., 2018). Therefore, researchers are trying to find a suitable solution for creating rapid point-of-care (POC) diagnostic devices to detect DENV markers at various DENV infection levels. The given review article focuses on different established and latest technologies for detecting DENV infection, including emerging diagnostic tools (Tab. 1).

\section{Virus Isolation}

The conventional methodologies for DENV infection detection include virus isolation, virus RNA or antigen detection, and serological tests. Virus isolation and culture are regarded as the standard gold method for virus detection. Virus isolation is a very specific and reliable method for viral infection diagnosis. The detection of a virus by an isolation method requires a culturing technique, a very lengthy process that needs a week or more for completion. The culturing of the sample requires specialized laboratory equipment and a skilled person. However, isolation requires high-level equipment and technical skills. The virus culturing process is time-consuming to grow dengue viruses on cell lines that take a lot of time, from 7 to 10 days. The culturing method is more conventional and less sensitive (Kumarasamy et al., 2007; Wasik et al., 2017).

\section{Serological Tests}

DENV diagnostic devices must diagnose the infection at an early stage. These methods must be designed specifically to detect the DENV antigen or antibodies. The dengue virus detection is dependent on the initial infection caused by the virus. The response of dengue virus causes the initial infection that replicates the virus and infects immune, dendritic, and endothelial cells. The rapid replication exhibits peak viremia and leads to the onset of symptoms. The required serological tests to be performed are dependent on the dynamics of infection, whether the infection is primary or secondary. The presence of dengue non-structural protein 1 (NS1) antigen signifies the acutephase infection with the dengue virus. The dengue virus and its associated components such as RNA or NSI antigens are detectable in serum, plasma, blood cells, and infected tissues within 1-2 days following infection up to 9 days with symptoms appearance (Flipse et al., 2016; St. John and Rathore, 2019). The serological tests can be performed during the viremic phase for the early serotype identification of the virus. The diagnosis is based on detecting the host immune response caused by dengue infection. The 
TABLE 1

Laboratory diagnostic methods for dengue infection

\begin{tabular}{|c|c|c|c|}
\hline Platform type & Advantages & Disadvantages & Biomarkers \\
\hline Virus Isolation & $\begin{array}{l}\text { Confirmation test } \\
\text { Specific } \\
\text { Serotyping }\end{array}$ & $\begin{array}{l}\text { Require laboratory equipment } \\
\text { Skilled person } \\
\text { Time taking }\end{array}$ & Virus \\
\hline Serological Tests & $\begin{array}{l}\text { Easy } \\
\text { Rapid testing }(4-6 \text { h) } \\
\text { Economical }\end{array}$ & $\begin{array}{l}\text { Expensive } \\
\text { Cross-reactivity causes false-positive }\end{array}$ & NS1, IgG or IgM \\
\hline Molecular Assays & $\begin{array}{l}\text { Confirmation test } \\
\text { Rapid testing }(24-48 \mathrm{~h}) \\
\text { Serotyping } \\
\text { High sensitivity } \\
\text { High specificity }\end{array}$ & $\begin{array}{l}\text { Sample contamination } \\
\text { Complicated equipment }\end{array}$ & RNA \\
\hline Quartz Crystal Microbalance & $\begin{array}{l}\text { Label free } \\
\text { Easy } \\
\text { Inexpensive } \\
\text { High sensitivity }\end{array}$ & $\begin{array}{l}\text { Interaction of external noise } \\
\text { Air fluctuations affect } \\
\text { Contamination }\end{array}$ & $\begin{array}{l}\text { NS1, } \\
\text { E-protein, viral genome }\end{array}$ \\
\hline Surface Plasmon Resonance & $\begin{array}{l}\text { Label free } \\
\text { Less sample require } \\
\text { High sensitivity } \\
\text { High throughput }\end{array}$ & Bulky apparatus & $\begin{array}{l}\text { IgM, } \\
\text { viral protein (NS1) }\end{array}$ \\
\hline Electrochemical Impedance Spectroscopy & $\begin{array}{l}\text { Label free } \\
\text { Easy } \\
\text { Inexpensive }\end{array}$ & $\begin{array}{l}\text { Time taking } \\
\text { Less sensitivity }\end{array}$ & Virus, oligonucleotide \\
\hline Lateral flow assay & $\begin{array}{l}\text { Rapid (15-20 min) } \\
\text { Easy } \\
\text { Inexpensive }\end{array}$ & $\begin{array}{l}\text { False-positive due to cross-reactivity } \\
\text { Less sensitivity } \\
\text { Less specificity }\end{array}$ & NS1, IgG or IgM \\
\hline
\end{tabular}

serological reaction patterns are different for primary and secondary infections, as illustrated in Fig. 1 (Hunsperger et al., 2016; Shan et al., 2017). In acute phase dengue infection, NS1 concentration has been estimated within the range of $0.04-2 \mu \mathrm{g} / \mathrm{mL}$ for primary infection, while for secondary infection within the range of $0.01-2 \mu \mathrm{g} / \mathrm{mL}$ (Alcon et al., 2002). The immune system develops the IgM antibodies to fight antigens after the primary infection. Therefore, the presence of IgM signifies the occurrence of recent viral infection (Cárdenas-Perea et al., 2020;
Halstead and Dans, 2019). Clinically, different serological detection methods are used to detect anti-dengue immunoglobulin $\mathrm{M}$ (IgM). The $\operatorname{IgM}$ can be detected for 5 or more days after the appearance of symptoms in infected patients, with high-level detection at 2 weeks post-infection and declined to undetectable levels within 2-3 months (Caraballo et al., 2020; Waickman et al., 2020). The IgM level could lead to false-positive results unless the consecutive samples were tested. The cross-reactivity of anti-dengue IgM with other flaviviruses can affect the virus detection results.

\section{Primary Dengue Infection}

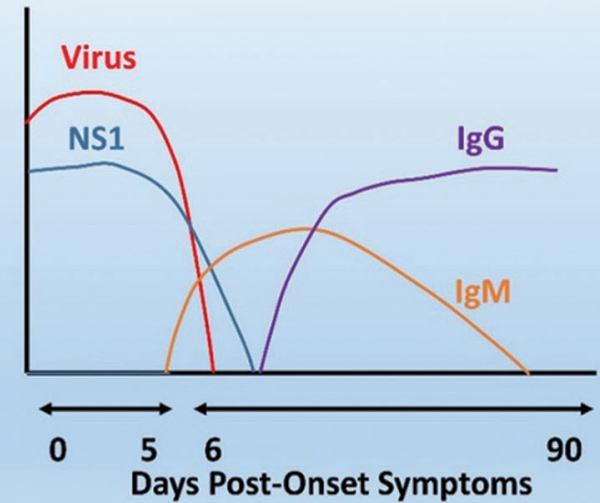

\section{Secondary Dengue Infection}

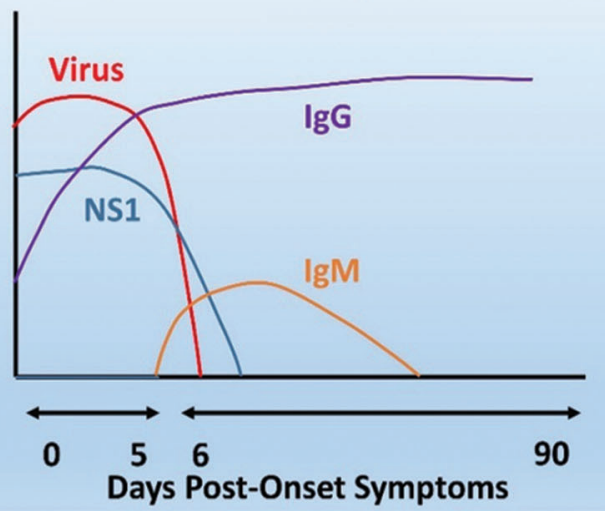

FIGURE 1. The progression of dengue virus, NS1 antigen, and $\mathrm{IgM} / \operatorname{IgG}$ for a primary and secondary infection. 
The diagnosis of dengue virus at an initial 5-8 days of the viremic period for a dengue patient can only be made using PCR. The early diagnosis of dengue virus is crucial for proper clinical treatments. Dengue-specific IgG appears at the end of the first week with low titers and increases slowly by a further titer increase. However, IgG is the long-term response of the body that can be detectable over several months to several decades, which complicates the serodiagnosis of current and past infections (Coarsey et al., 2019; Jang et al., 2019; Nascimento et al., 2018; Ortega et al., 2016). Indeed, serological tests can be affected by crossreactivity issues in areas where multiple Flavivirus are circulating. However, the risk of false-positive results can be reduced when $\operatorname{IgM} / \operatorname{IgG}$ testing is paired with NS1 antigen (Muller et al., 2017).

Serological assays are widely used to diagnose DENV infections because they are cost-effective and easy to operate. A magnetic immunoconjugate nanoplatform developed for easy colorimetric detection of the NS1 protein of dengue virus using infected serum (Maleki et al., 2020; RamírezNavarro et al., 2020). There are various serological kits available for detecting anti-DENV-specific immunoglobulin M (IgM) and immunoglobulin G (IgG) antibodies. The IgM antibodies can be detectable in plasma, saliva, and whole blood samples but cannot be detected in urine (Chien et al., 2018; Lai et al., 2019; Lee et al., 2019). An antigen-capturing anti-DENV IgA (ACA) ELISA can diagnose the DENV using saliva in an assay. The detection of primary dengue infection gives the sensitivity above $36 \%$. Whereas the secondary infection detection showed a significant value with $100 \%$ sensitivity (Yap et al., 2011). ACA-ELISA provides an economical platform for performing rapid tests without intruding samples. A Colorimetric ELISA is based on optical sensing and measuring the absorbance of light. The detection results showed a $95 \%$ sensitivity and $100 \%$ specificity when compared with commercially available ELISA. The method is automated, rapid, and can be performed at resource-limited settings (Thiha and Ibrahim, 2015). Zhang et al. (2014) has performed the NS1-based dengue diagnostic tests by using various ELISA kits. The resulted sensitivities and specificities of techniques are; Panbio Dengue Early ELISA Kit (63\% and 99\%), NS1 Ag ELISA Kit (71\% and 91\%), and Platelia Dengue NS1 Ag-ELISA Kit (69\% and 99\%). However, the detailed analysis shows that Dengue NS1 Ag STRIP Kit is more suitable for identifying and discriminating against DENV serotypes.

The ELISA and other serological tests are comparatively economical and easy to do tests compared to virus isolation and other methods. There are also some drawbacks associated with ELISA tests as cross-reactivity with other flaviviruses. Moreover, the efficiency of the serological tests depends on the level of infection. However, the current commercially available NS1 antigen detection kits cannot differentiate the serotypes of DENV, and results can be affected by the presence of previous virus-IgG immunocomplexes (Abe et al., 2020; Alejo-Cancho et al., 2020; Kathiresan et al., 2017).

\section{Molecular Assays}

The molecular methods based on reverse transcriptionpolymerase chain reaction (RT-PCR) are the latest standard methods for detecting virus RNA, over the conventional virus isolation. Several methods have been developed to amplify and detect the dengue serotypes in serum samples (Eivazzadeh-Keihan et al., 2019). The quantitative reverse transcription-polymerase chain reaction (Q-RT-PCR or Q-PCR) is a rapid and sensitive assay to identify four dengue serotypes using a clinical sample. However, the testing results show some complications when all or some serotypes were present in a single sample (Sadon et al., 2008). RT-PCR has shown promising results for detecting dengue virus in blood, saliva, and urine samples. RT-PCR is more feasible to perform when the blood sample is not enough or complicated to acquire, such as infants and patients with hemorrhagic syndromes (Poloni et al., 2010). The paper-based device that works with RT-LAMP (reverse transcription loop-mediated) was developed for detecting DENV-2 RNA in a buffer system. The amplified dengue virus using RT-LAMP can be detected with a concentration of $60 \mathrm{PFU} / \mathrm{mL}$ (Lo et al., 2012).

The multiplex reverse transcriptase-PCR (rRT-PCR) is more sensitive to quantifying the dengue serotypes by quantifying viral RNA compared with real-time PCR methods (Waggoner et al., 2013). The clinical testing was performed using single-tube multiplex RT- PCR and twostep nested RT-PCR to compare the output sensitivity and serotyping. The results revealed that single-tube multiplex RT-PCR is more promising for dengue detection and distinguishing serotypes (Mishra et al., 2011). Lai et al. (2007) have developed a rapid RT-PCR for DENV RNA detection utilizing SYBR Green I as the evaluation dye. The given method only detects the small number of samples because of the requirement of a pair of generic primers and four pairs of serotype-specific primers. The number of samples can be processed at the same time for serotyping. Similarly, the fluorogenic probes have been used in real-time assays to determine the dengue serotypes.

The current commercial diagnostic methods are expensive, require trained personnel, and not feasible to move to impoverished areas. These methods provide rapid detection, distinguish serotype, be highly sensitive, and be used for reproducible diagnosis for dengue. However, the detection sensitivity varies among serotypes. Limitations in PCR detection involve expensive instrumentation, the requirement of temperature-controlled conditions, and a highly-skilled operator. These methods can easily contaminate the sample and require a complex laboratory setup (Lardo et al., 2016; Luan et al., 2016).

\section{Quartz Crystal Microbalance (QCM)}

The QCM is an analytical tool susceptible to mass changes, measuring nanogram to microgram level variations in mass per unit area (Beißner et al., 2017; Torad et al., 2019). The piezoelectric effect is an intrinsic feature of certain materials, enabling mass detection by frequency monitoring (Speight and Cooper, 2012). The frequency response $(\Delta \mathrm{f})$ of oscillations can be affected by the change in mass $(\Delta \mathrm{m})$ onto the electrode surface of the quartz crystal due to molecular interactions taking place at the electrode in realtime (Fig. 2) (Lim et al., 2020; Neumann et al., 2018; Park and Lee, 2018; Thies et al., 2017). The QCM device is 


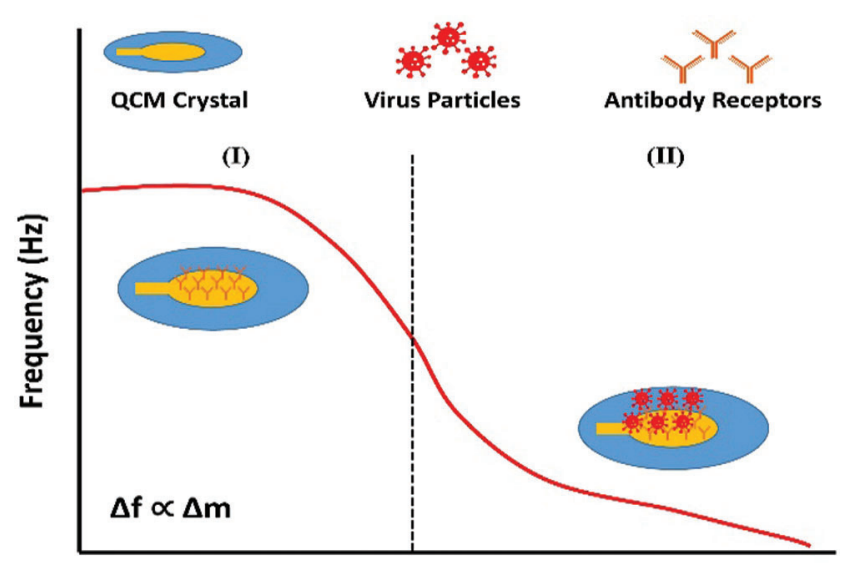

Time (s)

FIGURE 2. Principle of detection in QCM-based immunosensor. The variation in frequency response of the biosensor at two different phases: (I) QCM crystal with immobilized antibody receptor; (II) binding of target molecules to the receptors.

label-free and mass-sensitive over the other transducer devices. A circulating-flow QCM was developed by combining the oligonucleotide-functionalized gold nanoparticles with target sequence of DENV genome. The established method was able to detect dengue RNA from the serum. The acquired linear correlation was 0.987 with virus titration between $2-2 \times 10^{6}$ $\mathrm{PFU} / \mathrm{mL}$. The method is more sensitive, rapid, label-free, and does not require an expensive setup (Chen et al., 2009). Another piezoelectric sensor was developed by coating bacterial cellulose film for linking the monoclonal immunoglobulin G (IgGNS1), which will detect the NS1 protein of DENV. The device can detect the NS1 protein in the serum within the range of $0.01-10 \mu \mathrm{g} / \mathrm{mL}$ (Pirich et al., 2017).

Molecularly imprinted polymers (MIPs) are the biomimetic materials created to sense the specified target species. MIPs have been developed for targeting the dengue virus. MIP-based QCM sensors are used to detect the variation that occurs due to biological interaction of MIPs with dengue virus. The copolymer of methacrylic acid (MAA) and vinyl pyrrolidone (NVP) was optimized and cross-linked with ethylene glycol dimethacrylate (EGDMA) for creating MIPs for dengue virus. The QCM was coated with acquired MIPs to get the DENV detection measurements. The acquired linear correlation was 0.9959 for the target DENV. The research results indicate the possibility of future development of DENV biosensors using low-cost MIP (Lieberzeit et al., 2016). Another MIP has been developed using screen-printed carbon electrode modified with electrospun nanofibers of polysulfone. The fabricated material was coated with dopamine using NS1. The sensor showed linear response from 1-200 ng/mL with minimum selectivity of $0.3 \mathrm{ng} / \mathrm{mL}$ (Arshad et al., 2020; Maleki, 2018). Tai et al. (2006) developed artificial receptors by coating QCM with MIPs specific for NS1. The acquired correlation of QCM response and ELISA result was 0.73 .

Zainuddin et al. (2019) had developed a portable QCM device that connects with open-source software and hardware platform (OpenQCM). The system had achieved a low limit of detection of $10 \mathrm{ng} / \mathrm{mL}$, and the DENV identification test can be performed within $30 \mathrm{~min}$. These results signify POC device development with rapid and accurate dengue detection in resource-limited settings. QCM aptasensor was fabricated by thiolated aptamer immobilized on a gold electrode. Whereas aptamers are short nucleic acid sequences for binding a specific target molecule. Aptamers are used in biosensors as a biorecognition element (Eivazzadeh-Keihan et al., 2018; Iliuk et al., 2011). The sensor targets the available genome sequence of the DENV. Further, the surface plasmon resonance (SPR) was used to determine the molecular interaction of the virus with material. The QCM aptasensor can target the dengue genome within the range of $20-100$ $\mathrm{mg} / \mathrm{mL}$ (Sianghio et al., 2020). Another method was developed by using the DENV RNA obtained from mosquitos infected by dengue. The silver nanocluster strands were created by DNA acquired by DENV RNA to probe hybridization that can be visualized under UV light. The specific DENV DNA sequence produced a strong fluorescence upon the DNA hybridization kinetics. The DNA detection probe utilizes silver nanoclusters formation after target assisted isothermal exponential amplification for the detection of dengue. The method provided lower detection limits with $100 \mathrm{nM}$ of amplified target DNA of DENV, with higher fluorescence intensity (Chan et al., 2018). The fabricated DNA-QCM system utilizes sample pretreatment and DENV RNA extraction that makes the system very sensitive. The Nanoscale Optofluidic Sensor Arrays (NOSAs) were designed for Dengue virus detection. NOSAs use optical resonant devices, and their resonance wavelength shifted due to variation in the refractive index. The combination of a surface-bound molecule and its liquid phase target variates the refractive index. The device shows a refractive index sensitivity of $130 \mathrm{~nm}$ (Mandal and Erickson, 2008).

The advantages of QCM renders interesting for POC technology in early diagnosis of diseases. The QCM technique for DENV detection has several clinical and commercial benefits, e.g., economical production, rapid diagnosing, label-free, and easy to operate. Several disadvantages include long operation time, non-specific antigen recognition, natural antibody interactions, expensive and complicated equipment, sample preparation, and required dilution for complex samples (serum, blood, or urine) (Cai et al., 2018; Hong et al., 2017; Pohanka, 2020). The QCM devices cannot be operated in an open environment due to the requirement of controlled conditions. The possible interactions of external noise, air fluctuations, and contamination can affect the results and produce wrong results.

\section{Surface Plasmon Resonance (SPR)}

SPR is an optical technique that provides a label-free and highly specific detection of biomolecular interactions in realtime. The SPR detects the change in refractive index when the molecular interaction occurs between antigen and antibody. (Firdous et al., 2018; Hossain and Rana, 2016). The SPR applications have been employed for the rapid identification of DENV. 
Loureiro et al. (2017) proposed a simplified immunoassay for the rapid diagnosis of DENV serotypes. The immunoassay consists of four layers; the first layer is a gold thin film, the second layer is a Biotin film with sulfur. The third layer is composed of Neutravidin (NA), and the fourth layer is a Biotin mediated antibody attachment. The given approach has low-cost production and uses disposable polymer biochip. The outcomes did not show any false positive results for negative test control samples. The acquired limit of detection was approximately $2 \times 10^{4}$ viral particles per mm. An ultrasensitive signal transducer has been developed for DENV RNA using localized surface plasmon resonance. The biosensor was fabricated by conjugating alloyed shell quantum dots with gold nanoparticles. The biosensor can detect the nucleic acids of DENV1-DENV4 with high sensitivity and limit detection of 31-260 copies per $\mathrm{mL}$ for all serotypes (Adegoke and Park, 2017).

Austin Suthanthiraraj and Sen (2019) have developed the Localized surface plasmon resonance (LSPR) biosensor using silver nanostructures to detect dengue NS1 antigens. The detection test can be performed within 30 min using $10 \mu \mathrm{L}$ whole blood sample. The reported biosensor has detection reliability of $0.06 \mu \mathrm{g} / \mathrm{mL}$ within the range of clinical detection limit. The SPR optical sensor has been developed by fabricating immobilized monoclonal antibodies on the modified gold thin film. The interaction of DENV E-protein with fabricated film generated the SPR signal, used for the DENV detection. The dengue detection concentration values lie between $0.0001 \mathrm{nM}$ and $10 \mathrm{nM}$. There is a linear relationship between the shift in SPR angle and DENV E-protein concentration up to $0.01 \mathrm{nM}$. Further studies are required to improve the sensitivity and selectivity for detecting DENV in the early stage (Omar et al., 2018). The change in SPR shift for the PBS solution (without sample) and different concentrations of analyte give a difference in resonance angles that signifies the correct detection of DENV (Fig. 3) (Chen et al., 2016; Omar et al., 2020). Another optical biosensor has been developed for the rapid and qualitative detection of the DENV. The biosensor was fabricated by the combination of graphene-based material with surface plasmon resonance technique. The results depict that the sensor can detect the DENV from $0.1 \mathrm{pM}$ to $100 \mathrm{pM}$ (Omar et al., 2019). Another biosensor has been reported for the detection and serotyping of dengue virus. The biosensor was fabricated by using characterized quantum dots and gold nanoparticles. Four distinct probes were designed to distinguish the dengue serotypes. The biosensor can detect the target dengue virus RNA with virus dilutions from $10^{-15}$ to $10^{-10} \mathrm{M}$. The device has the limit of detection within the range of femtomolar, 24.6, $11.4,39.8$, and $39.7 \mathrm{fM}$ for DENV-1 to DENV-4, respectively (Chowdhury et al., 2020).

SPR has several advantages over conventional methods because they are economical, label-free, real-time detection, easy sample preparation, high throughput, and higher sensitivity (Bai et al., 2019; Wu et al., 2018). The use of nanoparticles for SPR makes the detection process possible in resource limited settings and outside laboratories. The drawback associated with SPR is the nonspecific binding that reduces accuracy. The conventional SPR devices require expensive apparatus, complex optical modules, and accurate arrangement of the constituents (Zhang et al., 2019).

\section{Electrochemical Impedance Spectroscopy (EIS)}

EIS-based biosensors evaluate the change in electrical impedance spectrum acquired by interactions of biomarkers

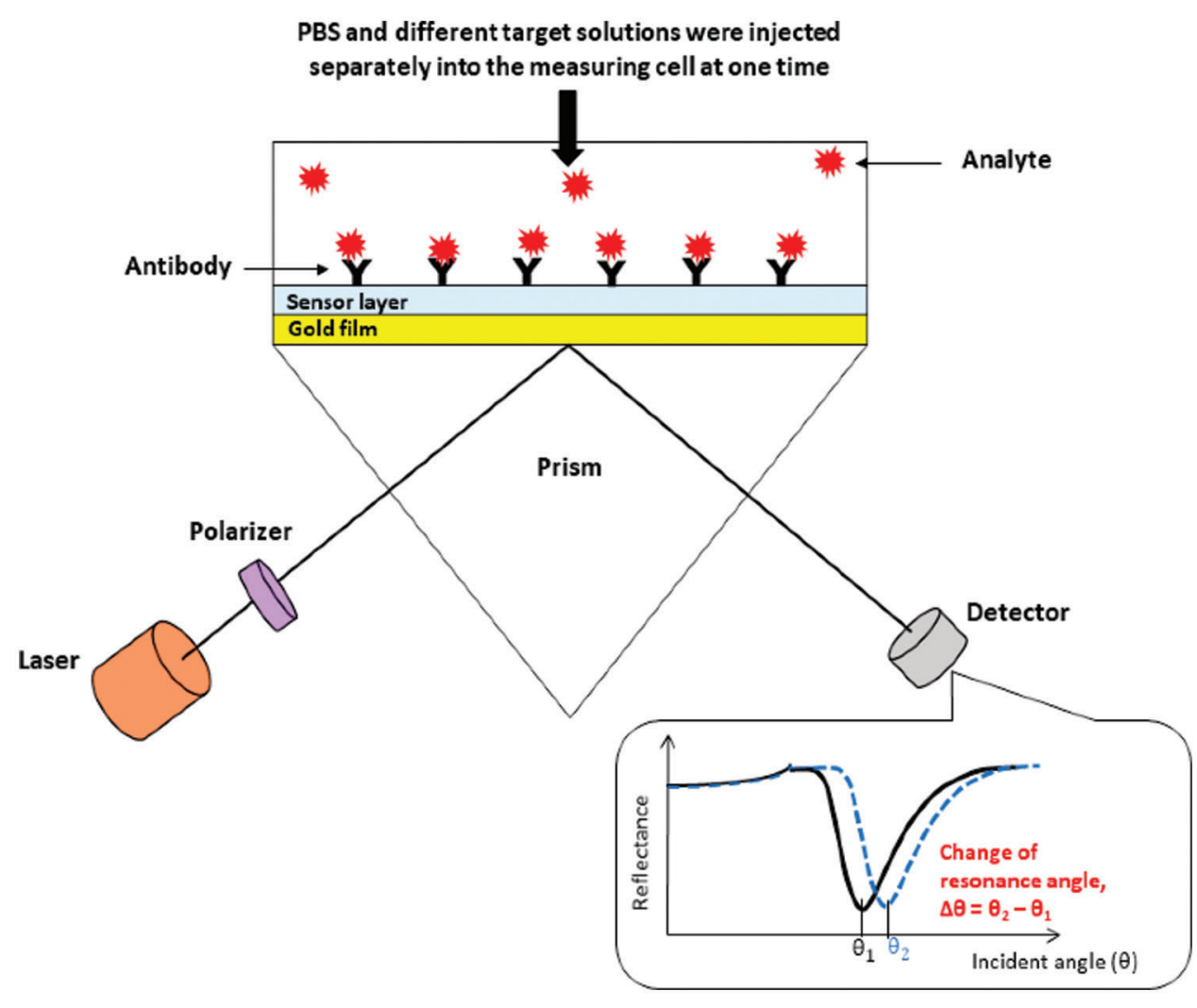

FIGURE 3. Schematic diagram of the surface plasmon resonance setup with description of the SPR curve and the change in resonance angle (Omar et al., 2020a). 
with biorecognition receptors. The device is composed of miniaturized electronic components that have advantages over the transduction schemes. Each reaction process in EIS represented by an electrical circuit containing resistance, capacitors, and combination of these elements in series or parallel. EIS monitors faradaic and non-faradaic processes in the interface between the electrode and solution. The Faradaic Electrochemical Impedance Spectroscopy (f-EIS) detect biorecognition events occur at the working electrode by measuring the change in current. Whereas the nonfaradaic Electrochemical Impedance Spectroscopy (nf-EIS), the process take place at working electrode without any charge transfer (Bahadır and Sezgintürk, 2016). The output result shows high sensitivity with low power consumption and lower production cost. The technique works without using optical components (Sacco, 2017; Siuzdak et al., 2019). The adsorption and desorption of analytes change the resistance value by charge transfer at the surface of electrode.

Biomedical devices are required antifouling surfaces to avoid non-specific interactions of proteins or cells. A labelfree electrochemical assay was developed with the antifouling component for dual detection of NS1 and IgG using a redox capacitive transducer. A low fouling component (PEG) has been used to avoid non-specific interactions. The NS1 detection results showed linear range of target concentration from $5-1000 \mathrm{ng} / \mathrm{mL}$ with LOD of $1.2 \mathrm{ng} / \mathrm{mL}$. Whereas the IgG detection showed a linear range of $1-1000 \mathrm{ng} / \mathrm{mL}$ with LOD of $231 \mathrm{pg} / \mathrm{mL}$ (Santos et al., 2018). A label-free immunosensor was developed based on a recordable compact disk (CD-trode) to detect the dengue virus. The biosensor was characterized by cyclic voltammetry and electrochemical impedance spectroscopy using anti-NS1. The results showed a linear response from 1 to $100 \mathrm{ng} / \mathrm{mL}$ of NS1 with a detection limit of $0.33 \mathrm{ng} / \mathrm{mL}$ (Cavalcanti et al., 2012). Another work has been reported for the detection of protein NS1 using an electrochemical immunosensor based on antibody-nanoparticle. The immunosensor provides a wide range of detection from 5 to $4000 \mathrm{ng} / \mathrm{mL}$ and coefficient of determination $\left(\mathrm{R}^{2}\right)$ of 0.94 . An alumina membrane has been fabricated using an electrochemical setup for the detection of dengue infection. The device showed good limit of detection for DENV 2 and DENV 3 with $0.230 \mathrm{PFU} / \mathrm{mL}$ and $0.710 \mathrm{PFU} / \mathrm{mL}$ values. The detection time is about $40 \mathrm{~min}$ with higher sensitivity. The given technique can be useful for developing disposable testing kits at clinical level. But the given method requires further investigation towards the detection of DENV 1 and DENV 4 viruses (Peh and Li, 2013).

An impedimetric transducer was successfully developed for detecting DENV anti-NS1. The transducer fabrication is based on the specific non-Structural Protein 1 (rNS1) antibodies immobilized over poly (4-aminobenzoic acid)modified screen-printed electrodes. The proposed work uses a small concentration of rNS1 antigen $(0.1 \mathrm{ng} / \mathrm{mL})$ with a serum dilution of 1:1280 (Santos et al., 2020). EIS has been used in many applications for diagnosing DENV as a POC device. One of the EIS biosensors was developed by gold electrode immobilized concanavalin-A (ConA) for probing glycoprotein patterns in blood during dengue. The binding of ConA lectin and DENV positive test sample causes an increase in the electron transfer resistance (Oliveira et al., 2009). An impedimetric label-free immunosensor was developed by an anti-NS1 modified gold electrode for the detection of NS1. The immunosensor can acquire NS1 in PBS with LOD of $3 \mathrm{ng} / \mathrm{mL}$, whereas the LOD of $30 \mathrm{ng} / \mathrm{mL}$ was recorded in serum samples (Cecchetto et al., 2015).

Overall, the biosensors based on electrochemical impedance spectroscopy can detect the antigens from the actual serum specimens with higher sensitivity and selectivity. These immunosensors also provide a wide range of detection, label-free detection with low cost and operational simplicity. The issues associated with EIS biosensors include complex experimental setup and the output results affected with specified virus samples from the heterogeneous mixture.

\section{Lateral Flow Assay (LFA)}

In the early 1980s, with the breakthrough of home pregnancy tests, the lateral flow assays LFAs have found a wide range of applications related to human health, food quality control, and environmental studies (Farka et al., 2020; Kuswandi, 2020). LFA technique is based on the biochemical bindings of antigen-antibody or probe DNA-target DNA hybridization. The standard LFA has four parts: a sample pad, on which the sample is dropped; conjugate pad, on which the labeled tags combined with biorecognition elements; reaction membrane that contains test line and control line for target DNA-probe DNA hybridization or antigen- antibody interaction; and absorbent pad that reserves waste as demonstrated in Fig. 4 (Bahadır and Sezgintürk, 2016; Chen et al., 2018). After dropping the sample onto the sample pad, it flows toward the conjugate pad and then through the nitrocellulose membrane. First, the target anti-DENV IgG and non-specific IgG of the sample bind to the labelled antibodies in the conjugate pad. The target complexes are intercepted as the target-labeled molecule complexes flow by the test line. The fluorescencelabeled non-specific IgG complexes flow across the control line and are linked with antibodies. Finally, the intensity of fluorescence was recorded based on the technique, and the results were intercepted accordingly (Chen et al., 2018; Bahadır and Sezgintürk, 2016).

Kumar et al. (2018) reported the tapered lateral flow immunoassay for the DENV detection with a testing time of $10 \mathrm{~min}$. The results showed rapid testing with a detection limit of $4.9 \mathrm{ng} / \mathrm{mL}$. However, the lower sensitivity of the device limits the usage for clinical applications. A point-ofcare testing methodology has been developed by recombinaseaided amplification and lateral-flow dipsticks to detect DENV rapidly. The detection test was performed by incubating the testing unit at $37^{\circ} \mathrm{C}$ for $20 \mathrm{~min}$. The acquired limit of detection was 10 copies $/ \mu \mathrm{L}$, the sensitivity was $98.2 \%$, and specificity was 100\% (Xiong et al., 2020).

Currently, there are several commercial immunochromatographic assays available for DENV diagnosis, including the Dengue NS1 Ag Strip (Bio-Rad Laboratories, France), MAC-ELISA (PanBio Diagnostics, Australia), and Dengue Eden Test Bioeasy (Standard Diagnosis, Korea). Various studies showed that commercially available kits have good sensitivity and specificity for diagnosing DENV. These available kits are easy to use and not expensive. BIOEASY can 

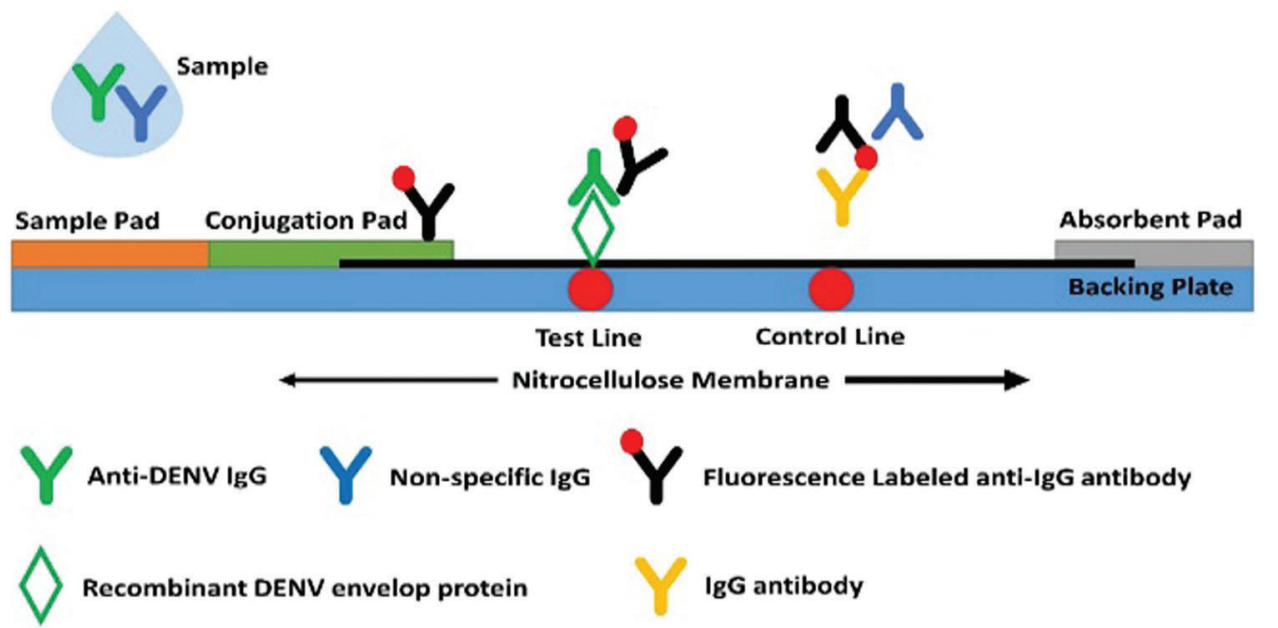

FIGURE 4. The schematic
representation and analytical
mechanism of the LFA strip. detect the DENV by using blood, plasma, and serum samples, without any chemical characterization or adding buffer. The testing will require only sample pipette. BIORAD requires human plasma and serum samples for testing DENV. Whereas the PANBIO can detect the DENV by using serum samples only. Therefore, BIORAD and PANBIO testing kits require sample centrifugation, additional buffering materials, and reagents. Hence, these two testing kits require more time and cost. The tested sensitivities for detecting DENV by BIOEASY, BIORAD and PANBIO 94.03\%, 91.04\% and 88.06\%, respectively (Ferraz et al., 2013). Mat Jusoh and Shueb (2017) have performed the performance evaluation for the commercially available kits to detect dengue virus. The sensitivities evaluated from the SD BIOLINE Dengue Duo (Standard Diagnostics Inc., Korea) and ProDetect Dengue Duo (Mediven) are $88.9 \%$ and $94.4 \%$, respectively. The overall sensitivity and specificity results from five different LFAs are presented in Tab. 2.

Future Perspectives and Electrical Biosensors Technologies The rapid detection of acute dengue virus infection is essential for its treatment and patient surveillance. Laboratory diagnosis is not feasible in resource-limited settings, including many dengue-endemic regions. The POC diagnosis test must fulfill WHO's ASSURED criteria that summarize affordable, sensitive, specific, user-friendly, rapid and robust, equipment-free, and deliverable to those in need (Bauer et al., 2017; Jacobsson et al., 2018). The necessity for quick and miniaturized POC tests for dengue virus detection has created many methods as an alternative to heavy lab instruments.

A sensor tip based on carbon nanotube-screen printed electrode was developed for dengue virus NS1 protein. The amperometric responses were generated with an applied potential of $-0.5 \mathrm{~V}$ vs. $\mathrm{Ag} / \mathrm{AgCl}$. The acquired results showed a LOD of $12 \mathrm{ng} / \mathrm{mL}$ (Dias et al., 2013). A separative extended gate field-effect transistor (SEGFET) has been designed for label-free detection of NS1. The Au electrodes were developed with anti-dengue NS1 antibodies and attached to the gate of MOSFET to create a SEGFET. The detection range for the recognition of NS1 is from 0.25 to $5.0 \mu \mathrm{g} / \mathrm{mL}$ (Vieira et al., 2014). The fluidic-based memristor sensor was used for dengue virus detection. The sensor was fabricated using the sol-gel spin coating technique and characterized chemically with an anti-dengue virus NS1 glycoprotein monoclonal antibody. The voltage-current (V-I) curve and characteristics were studied between the antibody-bound sensor surface with and without the viral protein. The results showed a sensitivity of $6.53 \times 10^{-3} \mathrm{nM}^{-1}$ and limit of detection of $5.02 \mathrm{~nm} / \mathrm{nM}$ based on fluidic-based characteristics. The output results are based on the change in electrical conductivity due to specific binding between the dengue virus antibody and NS1 glycoprotein of DENV (Hadis et al., 2017). The label-free DENV identification method has been developed by functionalized tampered optical fiber sensor and complimentary recombinant

TABLE 2

Sensitivity and specificity of commercial LFAs for dengue NS1 detection in patient sera

\begin{tabular}{llllll}
\hline & \multicolumn{2}{c}{ Sensitivity } & & \multicolumn{2}{c}{ Specificity } \\
\cline { 2 - 3 } Test & Samples & Outcomes & & Samples & Outcomes \\
\hline PRODETECT & 36 & $34(94.4 \%)$ & & 50 & $48(96.0 \%)$ \\
SD BIOLINE & 36 & $32(88.9 \%)$ & & 50 & $50(100.0 \%)$ \\
BIOEASY & 67 & $63(94.03 \%)$ & & 10 & $10(100 \%)$ \\
BIORAD & 67 & $61(91.04 \%)$ & & 10 & $10(100 \%)$ \\
PANBIO & 67 & $59(88.06 \%)$ & & 10 & $10(100 \%)$ \\
\hline
\end{tabular}


antibodies. The detection principle is dependent on the interaction of waves, and the surface of tapered fiber, the change in frequency wavelength occurs due to the presence of the virus at the surface. The tapered fiber is immobilized with DENV II E-specific antibodies. After placing the DENV II E proteins, they bound with DENV II antibodies. The change in surface characteristics of tapered fiber due to DENV II E proteins tends to variate the frequency wavelength. The basic prototype was developed for experimentation and recording the wavelength variation from sample using a biosensor based on tapered fiber. The acquired sensitivity of $5.02 \mathrm{~nm} / \mathrm{nM}$ and detection limit value of $1 \mathrm{pM}$ was recorded (Mustapha Kamil et al., 2018). The loop-mediated isothermal amplification (LAMP) method has been used for developing a portable device for early detection of dengue virus. The device can detect 16 viral infection species by observing fluorescence intensity (Kimura et al., 2019). Another portable device was fabricated based on reversetranscription loop-mediated isothermal amplification (RT-LAMP) and microfluidic platform for the simultaneous detection of zika, chikungunya, and dengue virus. The given POC device uses a commercial smartphone for acquiring real-time images of the amplification reaction, and a visual picture displays the read-out of the assay. The acquired limit of detection was $1.56 \times 10^{5} \mathrm{PFU} / \mathrm{mL}$ from the sample of whole blood. Cecchetto et al. proposed the serological POC and label-free capacitors diagnosis of DENV. The device works on the principle of variation in electrochemical capacitance to detect NS1 DENV biomarkers from the serum samples. The ferrocene-tagged peptide modified surface with anti-NS1 was used as a receptor. This strategy successfully differentiated positive control samples from a negative sample with $P<0.01$ (Cecchetto et al., 2020).

\section{Conclusion}

The rapid detection of dengue virus is essential at an early stage due to the unavailability of treatment and any reliable vaccine for dengue infection. The current DENV diagnostic tools are virus isolation, ELISA, and RT-PCR. Although these methods provide high accuracy in dengue diagnosis, they are time-consuming, expensive, and require skilled operators to perform detection tests. The commercially available antigen-based assays have been proven to be useful for the detection of the dengue NS1 protein. These assays provide rapid detection, user-friendly, and provides reliable diagnosis without use of any complicated devices. POC devices are desirable for DENV identification because it involves a single sample test with 'ready-to-use' reagents without laboratory vials and equipment. These instruments are compact, and unskilled person can perform the test at or near the POC. Therefore, the need for POC devices is significant, because of low-cost testing and short testing time. The current research is going on several latest techniques, and recent publications revealed much better identification results. Still, these techniques are in the research phase that requires clinical validation and need approval for human trials.
Copyright of Figures: Fig. 3 has been reused under the Creative Commons Attribution License of the article. The referenced article has been properly cited as "Omar NAS, Fen YW, Abdullah J, Sadrolhosseini AR, Mustapha Kamil Y, Fauzi NIM, Hashim HS, Mahdi MA (2020). Quantitative and selective surface plasmon resonance response based on a reduced graphene oxide-polyamidoamine nanocomposite for detection of dengue virus E-proteins. Nanomaterials 10: 569. DOI 10.3390/nano10030569."

Author Contribution: The authors confirm contribution to the paper as follows: study conception and design: Yongjun Tang, Junchen Zhu, Jianguo Dai; analysis and interpretation of results: Zeeshan Ali, Bin Liu, Xiaolong Liu; draft manuscript preparation: Mubashir Hussain. All authors reviewed the results and approved the final version of the manuscript.

Funding Statement: This work was supported by the Scientific Research Fund of the Shenzhen International cooperation projects under Grant Nos. (GJHZ20190819151403615), and the Natural Science Youth Foundation of China (61801307).

Conflicts of Interest: The authors declare that they have no conflicts of interest to report regarding the present study.

\section{References}

Abe H, Ushijima Y, Loembe MM, Bikangui R, Nguema-Ondo G et al. (2020). Re-emergence of dengue virus serotype 3 infections in Gabon in 2016-2017, and evidence for the risk of repeated dengue virus infections. International Journal of Infectious Diseases 91: 129-136. DOI 10.1016/j.ijid.2019.12.002.

Adegoke O, Park EY (2017). Bright luminescent optically engineered core/alloyed shell quantum dots: An ultrasensitive signal transducer for dengue virus RNA via localized surface plasmon resonance-induced hairpin hybridization. Journal of Materials Chemistry B 5: 3047-3058. DOI 10.1039/ C7TB00388A.

Ajlan BA, Alafif MM, Alawi MM, Akbar NA, Aldigs EK, Madani TA (2019). Assessment of the new World Health Organization's dengue classification for predicting severity of illness and level of healthcare required. PLoS Neglected Tropical Diseases 13: 1-16. DOI 10.1371/journal.pntd.0007144.

Alcon S, Talarmin A, Debruyne M, Falconar A, Deubel V, Flamand $M$ (2002). Enzyme-linked immunosorbent assay specific to dengue virus type 1 nonstructural protein NS1 reveals circulation of the antigen in the blood during the acute phase of disease in patients experiencing primary or secondary infections. Journal of Clinical Microbiology 40: 376-381. DOI 10.1128/JCM.40.02.376-381.2002.

Alejo-Cancho I, Navero-Castillejos J, Peiró-Mestres A, Albarracín R, Barrachina J et al. (2020). Evaluation of a novel microfluidic immuno-magnetic agglutination assay method for detection of dengue virus NS1 antigen. PLoS Neglected Tropical Diseases 14: e0008082. DOI 10.1371/journal.pntd.0008082.

Ali S, Gugliemini O, Harber S, Harrison A, Houle L et al. (2017). Environmental and social change drive the explosive emergence of zika virus in the Americas. PLoS Neglected Tropical Diseases 11: e0005135. DOI 10.1371/journal. pntd.0005135.

Arshad R, Rhouati A, Hayat A, Nawaz MH, Yameen MA, Mujahid A, Latif U (2020). MIP-based impedimetric sensor for detecting dengue fever biomarker. Applied Biochemistry and 
Biotechnology 191: 1384-1394. DOI 10.1007/s12010-02003285-y.

Austin Suthanthiraraj PP, Sen AK (2019). Localized surface plasmon resonance (LSPR) biosensor based on thermally annealed silver nanostructures with on-chip blood-plasma separation for the detection of dengue non-structural protein NS1 antigen. Biosensors and Bioelectronics 132: 38-46. DOI 10.1016/j.bios.2019.02.036.

Azeredo EL, Dos Santos FB, Barbosa LS, Souza TMA, BadolatoCorrêa J et al. (2018). Clinical and laboratory profile of zika and dengue infected patients: Lessons learned from the co-circulation of dengue, zika and chikungunya in Brazil. PLoS Currents 10: 10. DOI 10.1371/currents. outbreaks.0bf6aeb4d30824de63c4d5d745b217f5.

Bahadır EB, Sezgintürk MK (2016). A review on impedimetric biosensors. Artificial Cells, Nanomedicine, and Biotechnology 44: 248-262. DOI 10.3109/21691401.2014.942456.

Bahadır EB, Sezgintürk MK (2016). Lateral flow assays: Principles, designs and labels. TrAC Trends in Analytical Chemistry 82: 286-306. DOI 10.1016/j.trac.2016.06.006.

Bai H, Yuan M, Wang X, Wang X, Che J (2019). Development of a gold nanoparticle-functionalized surface plasmon resonance assay for the sensitive detection of monoclonal antibodies and its application in pharmacokinetics. Drug Metabolism and Disposition 47: 1361-1367. DOI 10.1124/dmd.119.086249.

Bauer WS, Kimmel DW, Adams NM, Gibson LE, Scherr TF et al. (2017). Magnetically-enabled biomarker extraction and delivery system: Towards integrated ASSURED diagnostic tools. Analyst 142: 1569-1580. DOI 10.1039/C7AN00278E.

Beißner S, Thies JW, Bechthold C, Kuhn P, Thürmann B, Dübel S, Dietzel A (2017). Low-cost, in-liquid measuring system using a novel compact oscillation circuit and quartz-crystal microbalances (QCMs) as a versatile biosensor platform. Journal of Sensors and Sensor Systems 2017: 341-350.

Beltrán-Silva SL, Chacón-Hernández SS, Moreno-Palacios E, Pereyra-Molina JÁ. (2018). Clinical and differential diagnosis: Dengue, chikungunya and zika. Revista Médica del Hospital General de México 81: 146-153. DOI 10.1016/j. hgmx.2016.09.011.

Billings L, Schwartz IB, Shaw LB, McCrary M, Burke DS, Cummings DAT (2007). Instabilities in multiserotype disease models with antibody-dependent enhancement. Journal of Theoretical Biology 246: 18-27. DOI 10.1016/j. jtbi.2006.12.023.

Cabezas S, Bracho G, Aloia AL, Adamson PJ, Bonder CS, Smith JR, Gordon DL, Carr JM (2018). Dengue virus induces increased activity of the complement alternative pathway in infected cells. Journal of Virology 92: e00633-e00618. DOI 10.1128/JVI.00633-18.

Cai S, Yan J, Xiong H, Liu Y, Peng D, Liu Z (2018). Investigations on the interface of nucleic acid aptamers and binding targets. Analyst 143: 5317-5338. DOI 10.1039/C8AN01467A.

Caraballo E, Poole-Smith BK, Tomashek KM, Torres-Velasquez B, Alvarado LI, Lorenzi OD, Ramos C, Carrión J, Hunsperger E (2020). The detection of anti-dengue virus IgM in urine in participants enrolled in an acute febrile illness study in Puerto Rico. PLoS Neglected Tropical Diseases 14: e0007971. DOI 10.1371/journal.pntd.0007971.

Cárdenas-Perea ME, Flores-Mendoza LK, Pérez-Contreras I, DíazOrea MA, Gómez-Conde E, Cortés-Hernández P, ReyesLeyva J, Santos-López G, Sosa-Jurado F (2020). Primary dengue infection in patients requiring hospitalization during an outbreak in a low incidence Mexican region.
Vector-Borne and Zoonotic Diseases 20: 380-386. DOI 10.1089/vbz.2019.2497.

Cavalcanti IT, Guedes MIF, Sotomayor MDPT, Yamanaka H, Dutra RF (2012). A label-free immunosensor based on recordable compact disk chip for early diagnostic of the dengue virus infection. Biochemical Engineering Journal 67: 225-230. DOI 10.1016/j.bej.2012.06.016.

Cecchetto J, Carvalho FC, Santos A, Fernandes FCB, Bueno PR (2015). An impedimetric biosensor to test neat serum for dengue diagnosis. Sensors and Actuators B: Chemical 213: 150-154. DOI 10.1016/j.snb.2015.02.068.

Cecchetto J, Santos A, Mondini A, Cilli EM, Bueno PR (2020). Serological point-of-care and label-free capacitive diagnosis of dengue virus infection. Biosensors and Bioelectronics 151: 111972. DOI 10.1016/j.bios.2019.111972.

Chan SK, Choong YS, Perera D, Lim TS (2018). Dengue serotyping with a label-free DNA sensor. Analytical Methods 10: 214-222. DOI 10.1039/C7AY02131C.

Chen H, Zheng X, Wang R, Gao N, Sheng Z, Fan D, Feng K, Liao X, An J (2016). Immunization with electroporation enhances the protective effect of a DNA vaccine candidate expressing prME antigen against dengue virus serotype 2 infection. Clinical Immunology 171: 41-49. DOI 10.1016/j.clim.2016.08.021.

Chen L, Wang H, Guo T, Xiao C, Liu L et al. (2018). A rapid point-ofcare test for dengue virus-1 based on a lateral flow assay with a near-infrared fluorescent dye. Journal of Immunological Methods 456: 23-27. DOI 10.1016/j.jim.2018.02.005.

Chen K, Zeng Y, Wang L, Gu D, He J, Wu SY, Shao Y et al. (2016). Fast spectral surface plasmon resonance imaging sensor for real-time high-throughput detection of biomolecular interactions. Journal of Biomedical Optics 21: 1-7. DOI 10.1117/1.JBO.21.12.127003.

Chen SH, Chuang YC, Lu YC, Lin HC, Yang YL, Lin CS (2009). A method of layer-by-layer gold nanoparticle hybridization in a quartz crystal microbalance DNA sensing system used to detect dengue virus. Nanotechnology 20: 215501. DOI 10.1088/0957-4484/20/21/215501.

Chien YW, Liu ZH, Tseng FC, Ho TC, Guo HR, Ko NY, Ko WC, Perng GC (2018). Prolonged persistence of IgM against dengue virus detected by commonly used commercial assays. BMC Infectious Diseases 18: 156. DOI 10.1186/s12879-018-3058-0.

Chong SE, Mohamad Zaini RH, Suraiya S, Lee KT, Lim JA (2017). The dangers of accepting a single diagnosis: Case report of concurrent Plasmodium knowlesi malaria and dengue infection. Malaria Journal 16: 1-8. DOI 10.1186/s12936-016-1666-y.

Chowdhury AD, Takemura K, Khorish IM, Nasrin F, Ngwe Tun MM, Morita K, Park EY (2020). The detection and identification of dengue virus serotypes with quantum dot and AuNP regulated localized surface plasmon resonance. Nanoscale Advances 2: 699-709. DOI 10.1039/C9NA00763F.

Chumpu R, Khamsemanan N, Nattee C (2019). The association between dengue incidences and provincial-level weather variables in Thailand from 2001 to 2014. PLoS One 14: e0226945. DOI 10.1371/journal.pone.0226945.

Coarsey C, Coleman B, Kabir MA, Sher M, Asghar W (2019). Development of a flow-free magnetic actuation platform for an automated microfluidic ELISA. RSC Advances 9: 81598168. DOI 10.1039/C8RA07607C.

Coudeville L, Baurin N, L'Azou M, Guy B (2016). Potential impact of dengue vaccination: Insights from two large-scale phase III trials with a tetravalent dengue vaccine. Vaccine 34: 64266435. DOI 10.1016/j.vaccine.2016.08.050. 
Darcy AW, Kanda S, Dalipanda T, Joshua C, Shimono T, Lamaningao P, Mishima N, Nishiyama T (2020). Multiple arboviral infections during a DENV-2 outbreak in Solomon Islands. Tropical Medicine and Health 48: 33. DOI 10.1186/ s41182-020-00217-8.

Darwish NT, Sekaran SD, Khor SM (2018). Point-of-care tests: A review of advances in the emerging diagnostic tools for dengue virus infection. Sensors and Actuators B: Chemical 255: 3316-3331. DOI 10.1016/j.snb.2017.09.159.

Durbin AP (2019). Dengue vascular leak syndrome: Insights into potentially new treatment modalities. Journal of Clinical Investigation 129: 4072-4073. DOI 10.1172/JCI131170.

Dias ACMS, Gomes-Filho SLR, Silva MMS, Dutra RF (2013). A sensor tip based on carbon nanotube-ink printed electrode for the dengue virus NS1 protein. Biosensors and Bioelectronics 44: 216-221. DOI 10.1016/j.bios.2012.12.033.

Eivazzadeh-Keihan R, Chenab KK, Taheri-Ledari R, Mosafer J, Hashemi SM, Mokhtarzadeh A, Maleki A, Hamblin MR (2020). Recent advances in the application of mesoporous silica-based nanomaterials for bone tissue engineering. Materials Science and Engineering C 107: 110267. DOI 10.1016/j.msec.2019.110267.

Eivazzadeh-Keihan R, Pashazadeh-Panahi P, Baradaran B, Maleki A, Hejazi M, Mokhtarzadeh A, de la Guardia M (2018). Recent advances on nanomaterial based electrochemical and optical aptasensors for detection of cancer biomarkers. Trends in Analytical Chemistry 100: 103-115. DOI 10.1016/j. trac.2017.12.019.

Eivazzadeh-Keihan R, Pashazadeh-Panahi P, Mahmoudi T, Chenab KK, Baradaran B, Hashemzaei M, Radinekiyan F, Mokhtarzadeh A, Maleki A (2019). Dengue virus: A review on advances in detection and trends - from conventional methods to novel biosensors. Microchimica Acta 186: 329. DOI 10.1007/s00604-019-3420-y.

Farka Z, Mickert MJ, Pastucha M, Mikušová Z, Skládal P, Gorris HH (2020). Advances in optical single-molecule detection: En route to supersensitive bioaffinity assays. Angewandte Chemie International Edition 59: 10746-10773. DOI 10.1002/anie.201913924.

Ferraz FO, Bomfim MRQ, Totola AH, Ávila TV, Cisalpino D et al. (2013). Evaluation of laboratory tests for dengue diagnosis in clinical specimens from consecutive patients with suspected dengue in Belo Horizonte, Brazil. Journal of Clinical Virology 58: 41-46. DOI 10.1016/j.jcv.2013.06.015.

Firdous S, Anwar S, Rafya R (2018). Development of surface plasmon resonance (SPR) biosensors for use in the diagnostics of malignant and infectious diseases. Laser Physics Letters 15: 065602. DOI 10.1088/1612-202x/aab43f.

Flipse J, Diosa-Toro MA, Hoornweg TE, van de Pol DPI, UrcuquiInchima S, Smit JM (2016). Antibody-dependent enhancement of dengue virus infection in primary human macrophages; balancing higher fusion against antiviral responses. Scientific Reports 6: 29201. DOI 10.1038/srep29201.

Hadis NSM, Manaf AA, Ngalim SH, Herman SH, Sawada K, Fauzi NA (2017). Fabrication of fluidic-based memristor sensor for dengue virus detection. 2017 IEEE Asia Pacific Conference on Postgraduate Research in Microelectronics and Electronics (PrimeAsia), pp. 105-108.

Halstead SB (2006). Dengue in the Americas and Southeast Asia: Do they differ? Revista Panamericana de Salud Pública 20: 407-415.

Halstead SB, Dans LF (2019). Dengue infection and advances in dengue vaccines for children. Lancet Child \& Adolescent Health 3: 734-741. DOI 10.1016/S2352-4642(19)30205-6.
Hong SR, Kim MS, Jeong HD, Hong S (2017). Development of realtime and quantitative QCM immunosensor for the rapid diagnosis of Aeromonas hydrophila infection. Aquaculture Research 48: 2055-2063. DOI 10.1111/are.13039.

Hossain MB, Rana MM (2016). DNA hybridization detection based on resonance frequency readout in graphene on $\mathrm{Au}$ SPR biosensor. Journal of Sensors 2016: 6070742. DOI 10.1155/ 2016/6070742.

Hsieh YH (2017). Ascertaining the impact of catastrophic events on dengue outbreak: The 2014 gas explosions in Kaohsiung. Taiwan PLoS One 12: e0177422. DOI 10.1371/journal. pone.0177422.

Hunsperger EA, Muñoz-Jordán J, Beltran M, Colón C, Carrión J et al. (2016). Performance of dengue diagnostic tests in a singlespecimen diagnostic algorithm. Journal of Infectious Diseases 214: 836-844. DOI 10.1093/infdis/jiw103.

Hussain M, Chen Z, Lv M, Xu J, Dong X et al. (2020a). Rapid and label-free classification of pathogens based on light scattering, reduced power spectral features and support vector machine. Chinese Chemical Letters. DOI 10.1016/j. cclet.2020.04.038.

Hussain M, Lv M, Dong X, Shen H, Wang W et al. (2020b). Design of rapid bacterial identification system based on scattering of laser light and classification of binned plots. Journal of Nanoscience and Nanotechnology 20: 4047-4056. DOI 10.1166/jnn.2020.17491.

Hussain M, Zhu S, Yang P, An Y, Li Z, Ali I, Liu B, Shen H, He N (2020c). Rapid detection system for hepatitis B surface antigen (HBsAg) based on immunomagnetic separation, multi-angle dynamic light scattering and support vector machine. IEEE Access 8: 107373-107386. DOI 10.1109/ ACCESS.2020.3000357.

Iliuk AB, Hu L, Tao WA (2011). Aptamer in bioanalytical applications. Analytical Chemistry 83: 4440-4452. DOI $10.1021 / \mathrm{ac} 201057 \mathrm{w}$.

Jacobsson S, Boiko I, Golparian D, Blondeel K, Kiarie J, Toskin I, Peeling RW, Unemo M (2018). WHO laboratory validation of Xpert $^{\oplus} \mathrm{CT} / \mathrm{NG}$ and Xpert ${ }^{\oplus}$ TV on the GeneXpert system verifies high performances. APMIS 126: 907-912. DOI 10.1111/apm.12902.

Jain S, Nehra M, Kumar R, Dilbaghi N, Hu T, Kumar S, Kaushik A, $\mathrm{Li} \mathrm{Cz}$ (2021). Internet of medical things (IoMT)-integrated biosensors for point-of-care testing of infectious diseases. Biosensors and Bioelectronics 179: 113074. DOI 10.1016/j. bios.2021.113074.

Jang WS, Kwak SY, May WL, Yang DJ, Nam J, Lim CS (2019). Comparative evaluation of three dengue duo rapid test kits to detect NS1, IgM, and IgG associated with acute dengue in children in Myanmar. PLoS One 14: e0213451. DOI 10.1371/journal.pone.0213451.

Jelinek T (2009). Trends in the epidemiology of dengue fever and their relevance for importation to Europe. Eurosurveillance 14: 19250 . DOI 10.2807/ese.14.25.19250-en.

Kathiresan E, Paramasivan R, Thenmozhi V, Das A, Dhananjeyan KJ, Sankar SG, Jerald Leo SV, Rathnapraba S, Vennison SJ (2017). Development and multi-use applications of dengue NS1 monoclonal antibody for early diagnosis. RSC Advances 7: 1927-1931. DOI 10.1039/C6RA24763F.

Kimura Y, Ikeuchi M, Inoue Y, Ikuta K (2019). Point of care testing chip for multiple virus infection detection using LAMP. 2019 IEEE 32nd International Conference on Micro Electro Mechanical Systems (MEMS), pp. 83-86. 
Kumar RP, Sunith R, Karthikeyan A, Kumar VP (2020). Dengue fever: A review article. International Journal of Current Microbiology and Applied Science 9: 1502-1510.

Kumar S, Bhushan P, Krishna V, Bhattacharya S (2018). Tapered lateral flow immunoassay based point-of-care diagnostic device for ultrasensitive colorimetric detection of dengue NS1. Biomicrofluidics 12: 034104. DOI 10.1063/1.5035113.

Kumarasamy V, Wahab AHA, Chua SK, Hassan Z, Chem YK, Mohamad M, Chua KB (2007). Evaluation of a commercial dengue NS1 antigen-capture ELISA for laboratory diagnosis of acute dengue virus infection. Journal of Virological Methods 140: 75-79. DOI 10.1016/j.jviromet.2006.11.001.

Kuo HJ, Lee IK, Liu JW (2018). Analyses of clinical and laboratory characteristics of dengue adults at their hospital presentations based on the World Health Organization clinical-phase framework: Emphasizing risk of severe dengue in the elderly. Journal of Microbiology, Immunology and Infection 51: 740-748. DOI 10.1016/j.jmii.2016.08.024.

Kuswandi B (2020). Advances and applications of lateral-flow nanostrip for point-of-care applications. In: Kanchi S, Sharma D (eds.), pp. 439-477, Nanomaterials in Diagnostic Tools and Devices. Elsevier.

Lai SC, Huang YY, Shu PY, Chang SF, Hsieh PS et al. (2019). Development of an enzyme-linked immunosorbent assay for rapid detection of dengue virus (DENV) NS1 and differentiation of DENV serotypes during early infection. Journal of Clinical Microbiology 57: e00221-e00219. DOI 10.1128/JCM.00221-19.

Lai YL, Chung YK, Tan HC, Yap HF, Yap G, Ooi EE, Ng LC (2007). Cost-effective real-time reverse transcriptase PCR (RT-PCR) to screen for Dengue virus followed by rapid single-tube multiplex RT-PCR for serotyping of the virus. Journal of Clinical Microbiology 45: 935-941. DOI 10.1128/jcm.01258-06.

Lardo S, Utami Y, Yohan B, Tarigan SMMU, Santoso WD, Nainggolan L, Sasmono RT (2016). Concurrent infections of dengue viruses serotype 2 and 3 in patient with severe dengue from Jakarta. Indonesia Asian Pacific Journal of Tropical Medicine 9: 134-140. DOI 10.1016/j. apjtm.2016.01.013.

Lee B, Rose E (2018). Other potentially life-threatening conditions with mucocutaneous findings (leptospirosis, typhoid fever, dengue, diphtheria, murine typhus). In: Rose E (eds.), pp. 319-347, Life-Threatening Rashes: An Illustrated, Practical Guide. Cham: Springer International Publishing.

Lee H, Ryu JH, Park HS, Park KH, Bae H et al. (2019). Comparison of six commercial diagnostic tests for the detection of dengue virus non-structural-1 antigen and IgM/IgG antibodies. Annals of Laboratory Medicine 39: 566-571. DOI 10.3343/ alm.2019.39.6.566.

Lieberzeit PA, Chunta S, Navakul K, Sangma C, Jungmann C (2016). Molecularly imprinted polymers for diagnostics: Sensing high density lipoprotein and dengue virus. Procedia Engineering 168: 101-104. DOI 10.1016/j.proeng.2016.11.157.

Lim HJ, Saha T, Tey BT, Tan WS, Ooi CW (2020). Quartz crystal microbalance-based biosensors as rapid diagnostic devices for infectious diseases. Biosensors and Bioelectronics 168: 112513. DOI 10.1016/j.bios.2020.112513.

Linn N, Kyaw K, Shewade H, Kyaw A, Tun M, Khine S, Linn N, Thi A, Lin Z (2020). Notified dengue deaths in Myanmar (201718): Profile and diagnosis delays [version 1; peer review: 2 approved, 1 approved with reservations]. F1000Research 9. DOI 10.12688/f1000research.23699.1.
Liu Y, Liu J, Cheng G (2016). Vaccines and immunization strategies for dengue prevention. Emerging Microbes \& Infections 5: 1-6. DOI 10.1038/emi.2016.74.

Lo S, Yang S, Yao D, Chen J, Cheng C (2012). Molecular-level dengue fever diagnostics via a combination of RT-LAMP and paperbased devices. 2012 IEEE Nanotechnology Materials and Devices Conference (NMDC2012), pp. 84-87.

Loureiro FCCL, Neff H, Melcher EUK, Roque RA, de Figueiredo RMP, Thirstrup C, Borre MB, Lima AMN (2017). Simplified immunoassay for rapid Dengue serotype diagnosis, revealing insensitivity to non-specific binding interference. Sensing and Bio-Sensing Research 13: 96-103. DOI 10.1016/j.sbsr.2016.10.002.

Luan H, Wang Y, Li Y, Cui Z, Chang S, Zhao P (2016). Development of a real-time quantitative RT-PCR to detect REV contamination in live vaccine. Poultry Science 95: 20232029. DOI 10.3382/ps/pew147.

Maleki A (2018). Green oxidation protocol: Selective conversions of alcohols and alkenes to aldehydes, ketones and epoxides by using a new multiwall carbon nanotubebased hybrid nanocatalyst via ultrasound irradiation. Ultrasonics Sonochemistry 40: 460-464. DOI 10.1016/j. ultsonch.2017.07.020.

Maleki A, Hassanzadeh-Afruzi F, Varzi Z, Esmaeili MS (2020). Magnetic dextrin nanobiomaterial: An organic-inorganic hybrid catalyst for the synthesis of biologically active polyhydroquinoline derivatives by asymmetric Hantzsch reaction. Materials Science and Engineering C 109: 110502. DOI 10.1016/j.msec.2019.110502.

Mandal S, Erickson D (2008). Nanoscale optofluidic sensor arrays. Optics Express 16: 1623-1631. DOI 10.1364/OE.16.001623.

Martina BEE, Koraka P, Osterhaus ADME (2009). Dengue virus pathogenesis: An integrated view. Clinical Microbiology Reviews 22: 564. DOI 10.1128/CMR.00035-09.

Mat Jusoh TNA, Shueb RH (2017). Performance evaluation of commercial dengue diagnostic tests for early detection of dengue in clinical samples. Journal of Tropical Medicine 2017: 4687182. DOI 10.1155/2017/4687182.

Meyding-Lamadé U, Craemer EM (2018). Winners of globalization: Dengue viruses and Japanese encephalitis virus-Diseases in neurology. Nervenarzt 89: 1338-1343. DOI 10.1007/s00115018-0616-z.

Mishra B, Sharma M, Pujhari SK, Appannanavar SB, Ratho RK (2011). Clinical applicability of single-tube multiplex reverse-transcriptase PCR in dengue virus diagnosis and serotyping. Journal of Clinical Laboratory Analysis 25: 76-78. DOI 10.1002/jcla.20434.

Muller DA, Depelsenaire ACI, Young PR (2017). Clinical and laboratory diagnosis of dengue virus infection. Journal of Infectious Diseases 215: S89-S95. DOI 10.1093/infdis/jiw649.

Mustafa MS, Rasotgi V, Jain S, Gupta V (2015). Discovery of fifth serotype of dengue virus (DENV-5): A new public health dilemma in dengue control. Medical Journal Armed Forces India 71: 67-70. DOI 10.1016/j.mjafi.2014.09.011.

Mustapha Kamil Y, Abu Bakar MH, Mustapa MA, Yaacob MH, Abidin NHZ, Syahir A, Lee HJ, Mahdi MA (2018). Labelfree Dengue E protein detection using a functionalized tapered optical fiber sensor. Sensors and Actuators B: Chemical 257: 820-828. DOI 10.1016/j.snb.2017.11.005.

Nascimento EJM, Huleatt JW, Cordeiro MT, Castanha PMS, George JK, Grebe E, Welte A, Brown M, Burke DS, Marques ETA (2018). Development of antibody biomarkers of long term 
and recent dengue virus infections. Journal of Virological Methods 257: 62-68. DOI 10.1016/j.jviromet.2018.04.009.

Nazemi H, Joseph A, Park J, Emadi A (2019). Advanced micro- and nano-gas sensor technology: A review. Sensors 19: 1285. DOI 10.3390/s19061285.

Neumann F, Madaboosi N, Hernández-Neuta I, Salas J, Ahlford A, Mecea V, Nilsson M (2018). QCM mass underestimation in molecular biotechnology: Proximity ligation assay for norovirus detection as a case study. Sensors and Actuators B: Chemical 273: 742-750. DOI 10.1016/j.snb.2018.06.025.

Normile D (2013). Surprising new dengue virus throws a spanner in disease control efforts. Science 342: 415. DOI 10.1126/ science.342.6157.415.

Oliveira MDL, Correia MTS, Diniz FB (2009). Concanavalin A and polyvinyl butyral use as a potential dengue electrochemical biosensor. Biosensors and Bioelectronics 25: 728-732. DOI 10.1016/j.bios.2009.08.009.

Omar NAS, Fen YW, Abdullah J, Chik CENCE, Mahdi MA (2018). Development of an optical sensor based on surface plasmon resonance phenomenon for diagnosis of dengue virus E-protein. Sensing and Bio-Sensing Research 20: 16-21. DOI 10.1016/j.sbsr.2018.06.001.

Omar NAS, Fen YW, Abdullah J, Sadrolhosseini AR, Mustapha Kamil Y, Fauzi NIM, Hashim HS, Mahdi MA (2020). Quantitative and selective surface plasmon resonance response based on a reduced graphene oxidepolyamidoamine nanocomposite for detection of dengue virus E-proteins. Nanomaterials 10: 569. DOI 10.3390/ nano10030569.

Omar NAS, Fen YW, Saleviter S, Daniyal WMEMM, Anas NAA, Ramdzan NSM, Roshidi MDA (2019). Development of a graphene-based surface plasmon resonance optical sensor chip for potential biomedical application. Materials 12: 1928. DOI $10.3390 / \mathrm{ma} 12121928$.

Ortega GA, Zuaznabar-Gardona JC, Morales-Tarré O, Reguera E (2016). Immobilization of dengue specific IgM antibodies on magnetite nanoparticles by using facile conjugation strategies. RSC Advances 6: 98457-98465. DOI 10.1039/ C6RA23260D.

Pang X, Zhang R, Cheng G (2017). Progress towards understanding the pathogenesis of dengue hemorrhagic fever. Virologica Sinica 32: 16-22. DOI 10.1007/s12250-016-3855-9.

Park HJ, Lee SS (2018). A quartz crystal microbalance-based biosensor for enzymatic detection of hemoglobin A1c in whole blood. Sensors and Actuators B: Chemical 258: 836-840. DOI 10.1016/j.snb.2017.11.170.

Peh AEK, Li SFY (2013). Dengue virus detection using impedance measured across nanoporous aluminamembrane. Biosensors and Bioelectronics 42: 391-396. DOI 10.1016/j.bios.2012.10.054.

Pirich CL, de Freitas RA, Torresi RM, Picheth GF, Sierakowski MR (2017). Piezoelectric immunochip coated with thin films of bacterial cellulose nanocrystals for dengue detection. Biosensors and Bioelectronics 92: 47-53. DOI 10.1016/j.bios.2017.01.068.

Pohanka M (2020). QCM immunosensor for the determination of Staphylococcus aureus antigen. Chemical Papers 74: 451-458. DOI 10.1007/s11696-019-00889-5.

Poloni TR, Oliveira AS, Alfonso HL, Galvão LR, Amarilla AA, Poloni DF, Figueiredo LT, Aquino VH (2010). Detection of dengue virus in saliva and urine by real time RT-PCR. Virology Journal 7: 22. DOI 10.1186/1743-422X-7-22.

Rahmasari FV, Wijayanti D, Khaerani N (2020). The correlation between blood parameters as early detection on dengue hemorrhagic fever (DHF) and dengue shock syndrome (DSS) in children. Bangladesh Journal of Medical Science 19: 273-277.

Ramírez-Navarro R, Polesnak P, Reyes-Leyva J, Haque U, VazquezChagoyán JC, Pedroza-Montero MR, Méndez-Rojas MA, Angulo-Molina A (2020). A magnetic immunoconjugate nanoplatform for easy colorimetric detection of the NS1 protein of dengue virus in infected serum. Nanoscale Advances 2: 3017-3026. DOI 10.1039/D0NA00251H.

Sacco A (2017). Electrochemical impedance spectroscopy: Fundamentals and application in dye-sensitized solar cells. Renewable and Sustainable Energy Reviews 79: 814-829. DOI 10.1016/j.rser.2017.05.159.

Sadon N, Delers A, Jarman RG, Klungthong C, Nisalak A, Gibbons RV, Vassilev V (2008). A new quantitative RT-PCR method for sensitive detection of dengue virus in serum samples. Journal of Virological Methods 153: 1-6. DOI 10.1016/j.jviromet.2008.06.023.

Santos A, Bueno PR, Davis JJ (2018). A dual marker label free electrochemical assay for Flavivirus dengue diagnosis. Biosensors and Bioelectronics 100: 519-525. DOI 10.1016/j. bios.2017.09.014.

Santos CDC, Santos PCM, Rocha KLS, Thomasini RL, de Oliveira DB, Franco DL, Ferreira LF (2020). A new tool for dengue virus diagnosis: Optimization and detection of anti-NS1 antibodies in serum samples by impedimetric transducers. Microchemical Journal 154: 104544. DOI 10.1016/j. microc.2019.104544.

Schwartz LM, Halloran ME, Durbin AP, Longini IM (2015). The dengue vaccine pipeline: Implications for the future of dengue control. Vaccine 33: 3293-3298. DOI 10.1016/j. vaccine.2015.05.010.

Shan C, Xie X, Ren P, Loeffelholz MJ, Yang Y, Furuya A, Dupuis AP, Kramer LD, Wong SJ, Shi PY (2017). A rapid zika diagnostic assay to measure neutralizing antibodies in patients. EBioMedicine 17: 157-162. DOI 10.1016/j.ebiom.2017.03.006.

Shukla R, Ramasamy V, Shanmugam RK, Ahuja R, Khanna N (2020). Antibody-dependent enhancement: A challenge for developing a safe dengue vaccine. Frontiers in Cellular and Infection Microbiology 10: 572681-572681. DOI 10.3389/ fcimb.2020.572681.

Sianghio GS, Dimaculangan RKA, Albano DRB (2020). Quartz crystal microbalance aptasensor for the molecular detection of dengue virus. ECS Meeting Abstracts 27: 1887-1887. DOI 10.1149/ma2020-01271887mtgabs.

Simo FBN, Bigna JJ, Kenmoe S, Ndangang MS, Temfack E, Moundipa PF, Demanou M (2019). Dengue virus infection in people residing in Africa: A systematic review and metaanalysis of prevalence studies. Scientific Reports 9: 13626. DOI 10.1038/s41598-019-50135-x.

Siuzdak K, Niedziałkowski P, Sobaszek M, Łęga T, Sawczak M, Czaczyk E, Dziąbowska K, Ossowski T, Nidzworski D, Bogdanowicz R (2019). Biomolecular influenza virus detection based on the electrochemical impedance spectroscopy using the nanocrystalline boron-doped diamond electrodes with covalently bound antibodies. Sensors and Actuators B: Chemical 280: 263-271. DOI 10.1016/j.snb.2018.10.005.

Speight RE, Cooper MA (2012). A survey of the 2010 quartz crystal microbalance literature. Journal of Molecular Recognition 25: 451-473. DOI 10.1002/jmr.2209.

St. John AL, Rathore APS (2019). Adaptive immune responses to primary and secondary dengue virus infections. Nature 
Reviews Immunology 19: 218-230. DOI 10.1038/s41577-0190123-X.

Tabachnick WJ (2016). Climate change and the arboviruses: Lessons from the evolution of the dengue and yellow fever viruses. Annual Review of Virology 3: 125-145. DOI 10.1146/ annurev-virology-110615-035630.

Tai DF, Lin CY, Wu TZ, Huang JH, Shu PY (2006). Artificial receptors in serologic tests for the early diagnosis of dengue virus infection. Clinical Chemistry 52: 1486-1491. DOI 10.1373/clinchem.2005.064501.

Tchuandom SB, Tchadji JC, Tchouangueu TF, Biloa MZ, Atabonkeng EP, Fumba MIM, Massom ES, Nchinda G, Kuiate JR (2019). A cross-sectional study of acute dengue infection in paediatric clinics in Cameroon. BMC Public Health 19: 958. DOI 10.1186/s12889-019-7252-9.

Thies JW, Kuhn P, Thürmann B, Dübel S, Dietzel A (2017). Microfluidic quartz-crystal-microbalance (QCM) sensors with specialized immunoassays for extended measurement range and improved reusability. Microelectronic Engineering 179: 25-30. DOI 10.1016/j.mee.2017.04.023.

Thiha A, Ibrahim F (2015). A colorimetric enzyme-linked immunosorbent assay (ELISA) detection platform for a point-of-care dengue detection system on a lab-on-compactdisc. Sensors 15: 11431-11441. DOI 10.3390/s150511431.

Torad NL, Zhang S, Amer WA, Ayad MM, Kim M, Kim J, Ding B, Zhang X, Kimura T, Yamauchi Y (2019). Advanced nanoporous material-based QCM devices: A new horizon of interfacial mass sensing technology. Advanced Materials Interfaces 6: 1900849. DOI 10.1002/admi.201900849.

Tsai JJ, Liu WL, Lin PC, Huang BY, Tsai CY et al. (2019). An RT-PCR panel for rapid serotyping of dengue virus serotypes 1 to 4 in human serum and mosquito on a field-deployable PCR system. PLoS One 14: e0214328. DOI 10.1371/journal.pone.0214328.

van Panhuis WG, Choisy M, Xiong X, Chok NS, Akarasewi P et al. (2015). Region-wide synchrony and traveling waves of dengue across eight countries in Southeast Asia. Proceedings of the National Academy of Sciences of the United States of America 112: 13069-13074. DOI 10.1073/ pnas.1501375112.

Vieira NCS, Figueiredo A, dos Santos JF, Aoki SM, Guimarães FEG, Zucolotto V (2014). Label-free electrical recognition of a dengue virus protein using the SEGFET simplified measurement system. Analytical Methods 6: 8882-8885. DOI 10.1039/C4AY01803F.
Waggoner JJ, Abeynayake J, Sahoo MK, Gresh L, Tellez Y et al. (2013). Single-Reaction, Multiplex, Real-Time RT-PCR for the Detection, Quantitation, and Serotyping of Dengue Viruses. PLoS Neglected Tropical Diseases 7: e2116. DOI 10.1371/journal.pntd.0002116.

Waickman AT, Gromowski GD, Rutvisuttinunt W, Li T, Siegfried H et al. (2020). Transcriptional and clonal characterization of B cell plasmablast diversity following primary and secondary natural DENV infection. EBioMedicine 54: 102733. DOI 10.1016/j.ebiom.2020.102733.

Wasik D, Mulchandani A, Yates MV (2017). A heparinfunctionalized carbon nanotube-based affinity biosensor for dengue virus. Biosensors and Bioelectronics 91: 811-816. DOI 10.1016/j.bios.2017.01.017.

Whitehead SS, Blaney JE, Durbin AP, Murphy BR (2007). Prospects for a dengue virus vaccine. Nature Reviews Microbiology 5: 518-528. DOI 10.1038/nrmicro1690.

Wu J, Li S, Wei H (2018). Multifunctional nanozymes: Enzyme-like catalytic activity combined with magnetism and surface plasmon resonance. Nanoscale Horizons 3: 367-382. DOI 10.1039/C8NH00070K.

Xiong Y, Luo Y, Li H, Wu W, Ruan X, Mu X (2020). Rapid visual detection of dengue virus by combining reverse transcription recombinase-aided amplification with lateralflow dipstick assay. International Journal of Infectious Diseases 95: 406-412. DOI 10.1016/j.ijid.2020.03.075.

Yap G, Sil BK, Ng LC (2011). Use of saliva for early dengue diagnosis. PLoS Neglected Tropical Diseases 5: e1046. DOI 10.1371/ journal.pntd.0001046.

Zainuddin AA, Nordin AN, Asri MAM, Ab Rahim R, Guines C, Chatras M, Pothier A, Mak WC (2019). Development of integrated electrochemical-quartz crystal microbalance biosensor arrays: Towards ultrasensitive, multiplexed and rapid point-of-care dengue detection. BioDevices, pp. 220227, Prague: Czech Republic.

Zhang CG, Chang SJ, Settu K, Chen CJ, Liu JT (2019). Highsensitivity glycated hemoglobin (HbAlc) aptasensor in rapid-prototyping surface plasmon resonance. Sensors and Actuators B: Chemical 279: 267-273. DOI 10.1016/j. snb.2018.09.077.

Zhang H, Li W, Wang J, Peng H, Che X, Chen X, Zhou Y (2014). NS1-based tests with diagnostic utility for confirming dengue infection: A meta-analysis. International Journal of Infectious Diseases 26: 57-66. DOI 10.1016/j.ijid.2014.02.002. 